\title{
THE EFFECT OF PROBLEMS ON SUPPLY CHAIN WIDE EFFICIENCY
}

\author{
MICHELINE J. NAUDE* \\ JOHANNA A. BADENHORST-WEISS** \\ *naudem@unkzn.ac.za \\ School of Management, University of KwaZulu-Natal \\ **badenja@unisa.ac.za \\ Department of Business Management, Unisa
}

\begin{abstract}
For any business to compete successfully in the modern, globalised business environment, it needs to mobilise its suppliers and customers to co-operate in order to reduce unnecessary costs and inefficiencies between them and to ensure the best value for the final customer. The focus is on management of the supply chain as a whole (or a system) and maximum value for the final customer of the supply chain, instead of on management for the maximum benefit of one of the parties in the supply chain. If the supply chain is seen as a system of organisations with one aim (value for the final customer), it is logical that a problem in one part of the supply chain must affect the workings and efficiency of the system or supply chain as a whole.
\end{abstract}

This article reports on an exploratory empirical study to illustrate the effect of problems at one party in the supply chain on the whole supply chain. The study was done at automotive component manufacturers. To determine how problems at one place permeate through the whole supply chain, correlation testing was done between supplyside, internal operations, and distribution or customer-side problems. The study found that problems experienced at one place in the supply chain had a negative impact throughout the supply chain. Automotive supply chains should therefore be managed more as a system, taking into consideration the effect of decision making and actions at one part of the supply chain on other parts of the supply chain. There should be a supply chain wide co-operative effort to find solutions to inefficiencies at all places in the supply chain.

\section{INTRODUCTION}

The automotive industry is often described as one of the most global of all industries. Its products are spread around the world and it is dominated by a small number of large companies with global recognition (Humphrey \& Memedovic, 2003:2).

Supply chain management (SCM) as a concept has been applied to some extent in the automotive industry for a number of decades. Candler (1998:6) noted as far back as 1998 a 
trend in the automotive industry. He noted that original equipment manufacturers (OEMs) do not want to deal with a large number of suppliers because this results in increased expenditure in administration, increased design costs and increased quality problems. Therefore, suppliers are rather organised into tiers of suppliers, where first-tier suppliers are left to design many of the assemblies themselves and second-tier suppliers assist in designing and producing the components.

The South African automotive industry has experienced significant changes in the last 20 years. Globalisation, the implementation of lean production and the development of modularisation have had major influences on the relationships between OEMs and their suppliers, particularly those in the first tier, known as automotive component manufacturers (ACMs) (Morris, Donnelly \& Donnelly, 2004:129).

The South African automotive industry experiences increasing operational complexities, rising fuel prices and higher human resources costs. This is a result of higher living costs and growing pressure from China and India to remain competitive. This has led to the industry's growing awareness of the impact of an efficient supply chain on business sustainability (Gabru, 2008). The South African automotive industry also suffered under the same economic climate (recession) as the international industry where governments had to intervene with aid packages to save the industry from total collapse. In South Africa, the negative economic condition led to the reduction and even closing down of operations to the extent that many employees in the industry were retrenched. In December 2008, 36000 people were employed by OEMs and 81500 were employed by ACMs. Since the global economic crisis the number of employees in the domestic automotive industry has declined with 16000 job losses (approximately 20\% of the total) in the ACM sector. Therefore as at March 2009, employment figures at ACMs were estimated to have fallen to 65500 employees (NAACAM, 2009:1).

The competitiveness and the struggle for survival of the automotive industry have never been as prominent as they are today. On average South Africa is $20 \%$ more expensive as a vehicle-manufacturing base than Western Europe, with China 12\% less expensive than Western Europe. That means that South Africa is 30 to $40 \%$ more expensive than China and India. The average local content on vehicles produced in South Africa is at $35 \%$, but it needs to grow to $70-75 \%$ in order to negate the costs of importing components using long supply chains and weathering a fluctuating currency (Venter, 2009). The improvement of the performance of South African automotive supply chains is therefore of the utmost importance.

Due to the poor competitiveness of South African automotive manufacturing in comparison with global competitors the question could be asked if all is well with the implementation 
of the SCM approach in this industry. Are there inefficiencies or problems that can be eliminated that will have a supply chain wide effect on efficiency?

The aim of the article is to focus attention on the systems (or network) nature of the SCM approach and to report on a study that had been done in the South African automotive industry to illustrate that inefficiencies or problems at one part of the supply chain have an impact on other parts of the supply chain. If these problems can be identified and eliminated at the source it might have an accumulating positive effect on supply chain wide efficiency.

\section{SUPPLY CHAIN MANAGEMENT}

Fierce competition in today's global markets, the introduction of products with short life cycles and the increased expectations of customers have forced businesses to invest in and focus their attention on their supply chains (Simchi-Levi, Kaminsky \& Simchi-Levi, 2009:1). The nature of competition has changed. Companies no longer compete against companies. Supply chains compete against other supply chains for supremacy. 'Toyota and its suppliers will clash with Ford and its suppliers for global competitive advantage' (Fawcett, Ellram \& Ogden, 2007:xvii).

The SCM concept or approach has developed as business organisations realise that both customers and suppliers can exert considerable influence on supply processes. Organisations need their suppliers to assist in decreasing costs, improving customer service and efficiency. Also, their customers need their co-operation as suppliers to further decrease costs, improve customer service and efficiency. ' ... the relationship between the company and its suppliers as well as its customers is included in the concept [of SCM]' (Van Weele, 2010:254-55).

Bennet and O'Kane (2006), Humphreys, Haung, Cadden and Mclvor (2007) and Lockström, Schadel, Harrison and Moser (2009) view SCM as a collaborative approach, spanning across firm boundaries, including various parties in the supply chain, which significantly contribute to improved product quality, shorter lead times and a higher responsiveness of the supply chain, at lower cost and increased customer-satisfaction levels.

The crux of the SCM approach perhaps lies in the summary of Van Weele (2010:255): 'SCM represents a systems approach to viewing the supply chain as an integrated entity rather than a set of fragmented parts.' A problem experienced in one element of the supply chain may relate to a weakness in another element or part of the supply chain. For example, if the suppliers or ACMs experience a build-up of inventory it might be caused by a lack of information sharing by OEMs (ACMs' customers). 'When customers are willing to share 
important planning information with their suppliers, this will enable them to anticipate much more effectively future customer orders' (Van Weele, 2010:255).

Key factors in the SCM approach became evident in the discussion of the concept of SCM above. It is clear that SCM consists of a series of businesses, integration of activities, a network of facilities, one unit as opposed to fragmented units and a system. The supply chain can therefore be seen as an integrated system. This means that good, efficient practices at suppliers, focal firms and customers in supply chains can improve the efficiency of the other parts (parties) and the supply chain as a whole. The opposite is also true. If inefficiencies or problems are experienced in one part, this negatively affects the other parts and the supply chain as a whole. One part should not be regarded as more important than the other. It is thus to the advantage of all the supply chain members if inefficiencies can be resolved together. 'Cost and inefficiencies go up when members of the supply chain fail to communicate and co-operate' (Fawcett et al., 2007:100).

SCM in the manufacturing of automotive components includes the integration of activities taking place among a network of facilities that procure the inputs needed at each level or tier of the supply chain, to be ultimately transformed into finished automotive components and delivered to customers through a distribution centre. Inputs include information from customers, raw materials, inventory, equipment, machinery, labour and finances. The transformation or conversion process transforms inputs such as raw material and labour into outputs in the form of finished goods and services delivered to the customer at the next lower level of the supply chain. This process is continued at all levels of the supply chain until the final product (a motor car) reaches the final customer. The facilities involved in an assembly-type supply chain such as ACMs include warehouses, factories, processing centres, distribution centres, retail outlets and offices. Activities include forecasting, planning, purchasing, inventory management, information management, quality assurance, scheduling production, distribution, delivery, disposal and customer service (Heizer \& Render, 2008:434; Stevenson, 2009:512).

Five critical factors for successful SCM in the automotive industry have been identified (which is in line with the critical success factors identified earlier). They are as follows (Gabru 2008):

1. A clear strategy for the entire supply chain that is tuned to market opportunities and focused on customer needs

2. Integrated organisational structures that enable the supply chain to operate as a single synchronised entity

3. An environment for excellent processes for implementing the strategy, which embraces all plan-source-make-deliver operations 
4. Reliable information using integrated technology to support effective supply chain planning, execution and decision making

5. Effective performance management of all supply chain operations to achieve revenue growth, best asset use and bottom-line profitability.

Two important aspects emerge from the discussion of SCM which need to be elaborated upon, particularly since the systems approach is emphasised in this article.

\section{Building relationships}

Traditionally the majority of business executives regarded the management of suppliers as insignificant in their overall performance. Buyers played suppliers off against each other and replaced suppliers frequently. This adversarial model was not ideal and today the model has transformed with international competitors demonstrating that joining forces with suppliers could lead to competitive market benefits (Handfield, Monczka, Giunipero \& Patterson, 2009:756). Stevenson (2005:718) confirms that maintaining good relationships with suppliers is increasingly being recognised as a critical factor in sustaining a competitive advantage. Numerous businesses view their suppliers as partners.

\section{Supply chain integration}

SCM revolves around efficient integration of suppliers, manufacturers, warehouses and stores. The challenge in supply chain integration is to co-ordinate activities across the supply chain so that the enterprise can improve performance: reduce costs, increase service level, reduce the bullwhip effect, better utilise resources and effectively respond to changes in the marketplace (Simchi-Levi et al., 2009:188).

Supply chain integration is described as 1) supply chain members using techniques enabling them to work together to optimise their collective performance in creation, distribution and support of the end product (Sundaram \& Metha, 2002:537); 2) the seamless flow of products and information from supplier to customer (Van Donk, Akkerman \& Van der Vaart, 2008:218); and 3) co-ordination mechanisms, all of which implies that business processes should be streamlined and interconnected, both within and outside the organisation's boundaries (Cagliano, Caniato \& Spina, 2006:283). The basis of integration can therefore be characterised by co-operation, collaboration, information sharing, trust, partnerships, shared technology and a fundamental shift away from managing individual functional processes to managing integrated chains of processes (Power, 2005:253).

Successful supply chain integration happens when the players realise that SCM must become part of all the business's strategic planning processes, in which the objectives and policies are jointly determined based on the final customers' needs and what the supply chain as a whole does well (Wisner, Tan \& Leong, 2009:23). 
SCM starts with internal integration and a move away from the silo approach to the systems approach, as indicated by Van Weele (2010:255). However, it does not stop with internal integration - as is clear from the definitions and description of SCM above. It requires external integration with other supply chain partners. Burt, Petcavage and Pinkerton (2010:529) are of the opinion that the majority of firms attempting to engage in SCM are still preoccupied with internal integration of functional activities and material and information flows. The real potential of SCM can be realised only after external integration of customers, key suppliers and information flows have been attained.

The question can be asked whether the role-players in the automotive supply chains do consider the supply chains' efficiency as more important than those of the individual organisation or supply chain party. Do they realise that actions and decisions on their part influence the efficiency of the supply chain as a whole?

\section{AIM OF THE ARTICLE}

The aim of the article is to focus attention on the systems or network nature of SCM and to report on a study that had been done in the South African automotive industry that illustrates that problems or inefficiencies at one part of the supply chain has a supply chain wide impact. This article may contribute to the refocusing of prominent supply chains on supply chain wide solutions.

\section{PROBLEM STATEMENT}

Due to the fact that supply chains function as a system or network, problems experienced in one part of the supply chain permeate through to the whole supply chain. This can lead to greater inefficiencies in the supply chain as a whole. More consideration should be given to the impact of actions and decisions in one part of the supply chain on the rest of the supply chain to ensure best decisions for the supply chain as a whole.

Due to the poor competitiveness of the South African automotive industry in comparison with global competitors, the question could be asked if the SCM approach is implemented to the fullest extent with a focus on supply chain wide solutions and efficiencies instead of those of individual parties in the supply chain. The problem investigated in this study tries to find an answer to the following question:

Is there evidence of supply chain inefficiencies or problems that permeate through to the whole supply chain in the automotive industry in South Africa? 
This study makes an effort to show that supply chain problems cannot be seen in isolation. They permeate through to the whole supply chain. If those problems can be identified and solved, it can lead to better efficiency for the supply chain as a whole.

In line with the research problem, the objective of this research was to determine whether there is a relationship between supply-side and internal supply chain problems, and supplyside and customer-side problems in automotive supply chains.

\section{RESEARCH METHODOLOGY}

The study which forms the basis of this article was both descriptive and exploratory and was mainly a quantitative study with some qualitative inputs. The empirical research was conducted in the automotive industry from the ACMs' perspective.

Based on a thorough literature study and semi-structured interviews with senior managers at OEMs in the automotive supply chains as inputs (which are not covered in this article), a questionnaire was designed for a survey with the aim of identifying problems and the extent of problems experienced in the automotive supply chains from an ACM perspective. A list of The National Association of Automotive Component and Allied Manufacturers (NAACAM) members was used in this study as the largest and most important ACMs in South Africa are members of this association. ${ }^{1}$ A total of 173 questionnaires was sent to respondents and a response rate of $30.6 \%$ was achieved.

The questionnaire was compiled to measure the extent to which the responding ACMs were experiencing various SCM problems outlined therein. The questionnaire used sevenpoint Likert scale items varying from 1 to 7 to determine whether respondents experienced particular supply chain problems and to what extent they experienced these problems. The questions included a qualitative section where respondents could motivate or qualify their answers. Descriptive and inferential statistics were used to determine the significance of the SCM problems.

To determine whether there is a relationship between problems experienced at the different parts in the supply chain (in line with the objectives of the research and the aim of this article) correlations were determined between the problems experienced at different parts in the supply chain. Spearman correlation coefficients were calculated and tested for significance.

1 Approximately $60 \%$ of $A C M$ s, including the most prominent ones, belong to the association NAACAM. The annual sales for NAACAM members totalled around US\$6-billion in 2008 (SA Automotive Week, 22 July 2009; http://naacam.bluebox.co.za/?profile). 


\section{FINDINGS AND DISCUSSION}

\section{Findings with regard to supply chain problems experienced by ACMs}

Table 1 represents a summary of the significant supply chain problems experienced in automotive supply chains from the ACMs' perspective. It is clear that of the 28 supply chain problems identified, the most significant was in the customer-side category, followed by the internal supply chain category.

Table 1: Significant supply chain problems

\begin{tabular}{|c|c|c|c|c|c|c|c|}
\hline & \multirow[t]{2}{*}{ Problem } & \multirow[t]{2}{*}{ Mean } & \multirow[t]{2}{*}{ Median } & \multicolumn{2}{|c|}{ Quartiles } & \multirow{2}{*}{$\begin{array}{l}\text { No. of } \\
\text { valid } \\
\text { cases }\end{array}$} & \multirow{2}{*}{$\begin{array}{l}\% \text { of } \\
\text { valid } \\
\text { cases }\end{array}$} \\
\hline & & & & 25 & 75 & & \\
\hline & Supplier-side problems & & & & & & \\
\hline 1. & Price of materials & 4.38 & 4.50 & 3.00 & 6.00 & 50 & 94.34 \\
\hline 2. & $\begin{array}{l}\text { BBBEE - achieving and verifying BEE } \\
\text { scorecards (in respect of OEMs' target) }\end{array}$ & 4.29 & 4.00 & 3.00 & 6.00 & 41 & 77.36 \\
\hline 3. & $\begin{array}{l}\text { Financial stability of suppliers (after the } \\
\text { onset of the recent economic crisis) }\end{array}$ & 4.09 & 4.00 & 3.00 & 5.00 & 43 & 81.13 \\
\hline 4. & $\begin{array}{l}\text { Material lead times too long, resulting in } \\
\text { obsolescence }\end{array}$ & 4.02 & 4.50 & 2.00 & 6.00 & 46 & 86.79 \\
\hline 5. & $\begin{array}{l}\text { Trust between you and your 'worst 10\%' } \\
\text { of suppliers }\end{array}$ & 3.73 & 4.00 & 3.00 & 5.00 & 44 & 83.02 \\
\hline 6. & Delivery of the right quality & 3.28 & 3.00 & 2.00 & 4.25 & 40 & 75.47 \\
\hline 7. & On-time delivery & 3.12 & 3.00 & 2.00 & 4.00 & 42 & 79.25 \\
\hline \multirow[t]{2}{*}{8.} & Supplier capacity limitations & 3.05 & 3.00 & 2.00 & 4.00 & 39 & 73.58 \\
\hline & Internal supply chain problems & & & & & & \\
\hline 9. & Cost of replacing outdated technology & 4.79 & 5.00 & 4.00 & 6.00 & 39 & 73.58 \\
\hline 10. & $\begin{array}{l}\text { Capacity limitations due to capital } \\
\text { funding }\end{array}$ & 4.21 & 4.00 & 3.00 & 6.00 & 28 & 52.83 \\
\hline 11. & $\begin{array}{l}\text { Output based on customer's forecast to } \\
\text { plan }\end{array}$ & 4.20 & 4.00 & 3.00 & 5.00 & 41 & 77.36 \\
\hline 12. & Labour problems - availability of skills & 4.16 & 4.00 & 3.00 & 6.00 & 43 & 81.13 \\
\hline 13. & $\begin{array}{l}\text { Labour problems - time consuming to } \\
\text { resolve }\end{array}$ & 4.08 & 4.00 & 3.00 & 5.00 & 37 & 69.81 \\
\hline 14. & $\begin{array}{l}\text { Capacity limitations due to customer } \\
\text { order fluctuation }\end{array}$ & 4.05 & 4.00 & 3.00 & 5.25 & 40 & 75.47 \\
\hline 15. & Reducing cycle time & 3.97 & 4.00 & 3.00 & 5.00 & 34 & 64.15 \\
\hline 16. & Balancing inventory levels & 3.91 & 4.00 & 3.00 & 5.00 & 43 & 81.13 \\
\hline 17. & Integrating information systems internally & 3.88 & 4.00 & 3.00 & 5.00 & 40 & 75.47 \\
\hline 18. & $\begin{array}{l}\text { Capacity limitations due to availability of } \\
\text { skilled labour }\end{array}$ & 3.75 & 4.00 & 2.00 & 5.00 & 36 & 67.92 \\
\hline 19. & $\begin{array}{l}\text { Integrating technology with suppliers and } \\
\text { customers }\end{array}$ & 3.67 & 3.00 & 2.5 & 5.00 & 39 & 73.58 \\
\hline
\end{tabular}




\begin{tabular}{|c|l|c|c|c|c|c|c|}
\hline & Customer-side problems & & & & & & \\
\hline 20. & Pressure by OEMs to reduce prices & 5.51 & 6.00 & 4.00 & 7.00 & 49 & 92.45 \\
\hline 21. & $\begin{array}{l}\text { Cancellation of orders (post the recent } \\
\text { economic crisis) }\end{array}$ & 5.02 & 5.00 & 4.00 & 6.00 & 49 & 92.45 \\
\hline 22. & $\begin{array}{l}\text { Excessive slow-moving inventory due to } \\
\text { cancellation of orders }\end{array}$ & 4.83 & 5.00 & 3.50 & 6.00 & 47 & 88.68 \\
\hline 23. & $\begin{array}{l}\text { Rapid changes in demand (in terms of } \\
\text { quantity patterns) }\end{array}$ & 4.18 & 4.00 & 3.00 & 5.00 & 44 & 83.02 \\
\hline 24. & $\begin{array}{l}\text { Advance communication about market } \\
\text { demand }\end{array}$ & 4.15 & 4.00 & 3.00 & 5.00 & 41 & 77.36 \\
\hline 25. & $\begin{array}{l}\text { Too dependent on business of a } \\
\text { particular customer }\end{array}$ & 4.15 & 4.00 & 2.00 & 6.00 & 41 & 77.36 \\
\hline 26. & $\begin{array}{l}\text { Trust between you and your 'worst' } \\
\text { customers }\end{array}$ & 4.13 & 4.00 & 3.00 & 6.00 & 39 & 73.58 \\
\hline 27. & Relationship with 'worst 10\%' customers & 4.12 & 4.00 & 3.00 & 6.00 & 34 & 64.15 \\
\hline 28. & $\begin{array}{l}\text { Little/no assistance from customers in } \\
\text { complying with their requirements }\end{array}$ & 3.79 & 4.00 & 2.50 & 5.00 & 43 & 81.13 \\
\hline
\end{tabular}

The individual problems will not be discussed in detail, because the main aim of this article is to determine if there is a relationship (correlation) between problems at different parts (parties) in the supply chain.

Briefly, on the supplier side (supply of raw materials and components to ACMs) the price of materials seems to be the greatest problem. ACMs indicated in the qualitative part that they have little or no leverage with particularly overseas suppliers with regard to price of raw materials and components. ACMs find it difficult to find reliable suppliers in the BEE category, and as expected, the financial stability of suppliers after the world-wide economic downturn. Material lead times that are too long, not being able to trust some suppliers, quality of materials, on-time delivery and capacity of suppliers were indicated as additional significant problems.

With regard to the internal supply chain, $\mathrm{ACMs}$ experienced the greatest problems with technology, capacity, and dependence on OEMs' demand forecasting and labour problems. Reducing cycle times and balancing inventory levels were also indicated as problems.

On the customer-side (OEMs), ACMs are pressured by OEMs to reduce prices. OEMs also cancelled orders during the economic downturn which resulted in excessive slowmoving inventory. ACMs have particular problems with the demand planning of OEMs and communication of demand planning information to them. ACMs feel that they are too dependent on particular OEMs and have relationship problems with some of their customers. 


\section{Findings regarding the relationship between problems on the supply side, the internal operations and distribution side of the automotive supply chain}

Figure 1 demonstrates the groups of supply chain factors/problems that may have relationships (correlations) between them (supply-side problems, problems in internal supply chains and distribution-side problems). In order to determine a correlation, the Spearman correlation coefficients were calculated and tested for significance.

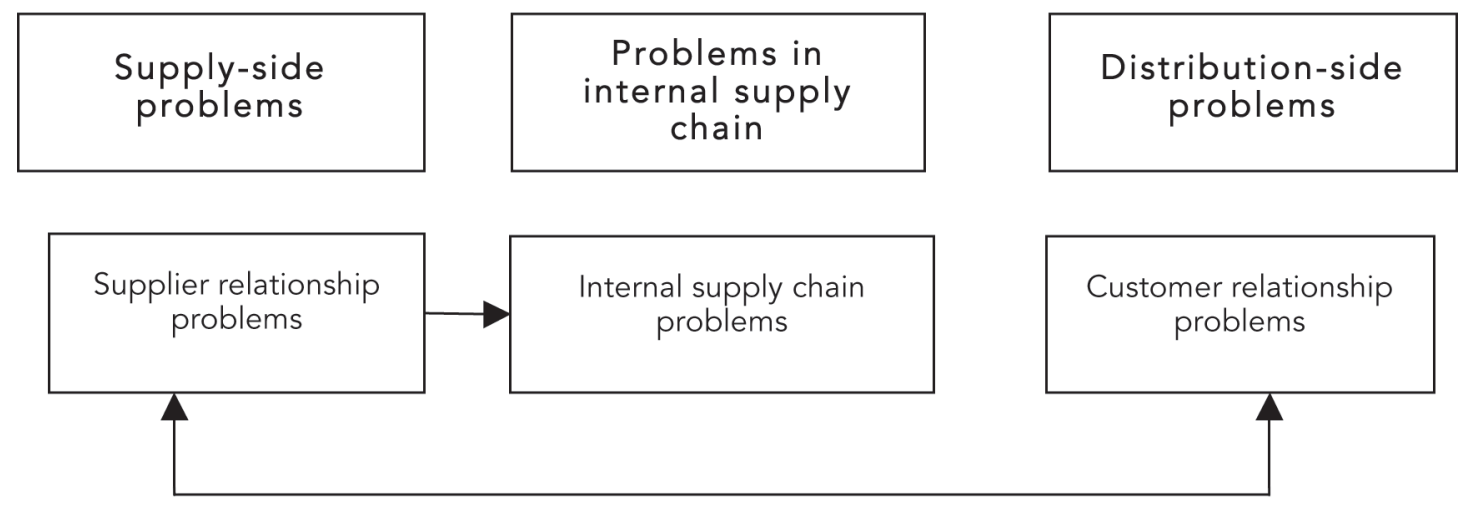

Figure 1: Conceptual model for relationships (correlations) testing

The problems on the supply side were used to determine whether there is a relationship between the supply side and problems experienced in the other parts (internal and customer sides) of the chain. The results are presented in Tables 2 to 7 . Each table (Tables 2 to 7 ) indicates those problems in which there is a statistically significant correlation with problems in the other part of the supply chain.

Table 2: Significant correlation between purchasing price of materials and other supply chain problems

\begin{tabular}{|l|c|c|c|c|}
\hline Problem & $\begin{array}{c}\text { Spearman's } \\
\text { rank-order } \\
\text { correlation }\end{array}$ & $\begin{array}{c}\text { Sig } \\
\text { (2-tailed) }\end{array}$ & Mean & N \\
\hline Internal supply chain problems & & & & \\
\hline Capacity limitations due to customer order fluctuations & $.339^{\star}$ & .035 & 4.05 & 39 \\
\hline Output based on (OEMs') customer forecasts to plan & $.332^{\star}$ & .039 & 4.20 & 39 \\
\hline Customer-side problems & & & & \\
\hline Cancellation of orders (after the recent economic crisis) & $.296^{\star}$ & .044 & 5.02 & 47 \\
\hline Pressure by OEMs to reduce prices & $.462^{\star \star}$ & .001 & 5.51 & 46 \\
\hline Relationship with 'worst 10\%' of customers & $.452^{\star \star}$ & .008 & 4.12 & 33 \\
\hline
\end{tabular}

* Correlation is significant at the 0.05 level (2-tailed).

** Correlation is significant at the 0.01 level (2-tailed). 
Table 2 indicates a statistically significant correlation between the problem of the purchasing price of materials and other supply chain problems The correlation between purchasing price and 'pressure by OEMs to reduce prices' can be explained as high prices of input materials permeate through the supply chain resulting in high prices to OEMs. If the purchasing price of input materials into the supply chain can be reduced it may lead to lower cost for the rest of the supply chain. There are no logical explanations for the correlation between the purchasing price of materials and some of the other significant problems in the supply chain in Table 2.

Table 3: Significant correlation between financial stability of suppliers and other supply chain problems

\begin{tabular}{|l|c|c|c|c|}
\hline Problem & $\begin{array}{c}\text { Spearman's } \\
\text { rank-order } \\
\text { correlation }\end{array}$ & $\begin{array}{c}\text { Sig } \\
\text { (2-tailed) }\end{array}$ & Mean & N \\
\hline Internal supply chain problems & & & & \\
\hline Capacity limitations due to customer order fluctuations & $.442^{\star}$ & .013 & 4.05 & 31 \\
\hline Customer-side problems & & & & \\
\hline Order fluctuations (prior to the recent economic crisis) & $.352^{\star}$ & .041 & 3.68 & 34 \\
\hline $\begin{array}{l}\text { Little/no assistance from customers to comply with their } \\
\text { requirements }\end{array}$ & $.581^{\star \star}$ & .000 & 3.79 & 32 \\
\hline Rapid changes in demand (in terms of quantity) patterns & $.402^{\star}$ & .022 & 4.18 & 32 \\
\hline Too dependent on the business of a particular customer & $.372^{\star \star}$ & .047 & 4.15 & 29 \\
\hline
\end{tabular}

* Correlation is significant at the 0.05 level (2-tailed).

** Correlation is significant at the 0.01 level (2-tailed).

Table 3 indicates a statistically significant correlation between the problem of suppliers' financial stability and 'customer order fluctuations', 'rapid changes in demand', and 'dependence on a particular customer' can be explained by what the different parties experienced during the economic downturn (as was the case at the time the study was conducted). The rapid decline in the demand for motor vehicles influenced the financial stability of all parties in the supply chain. Economic problems are not controllable by SCM and alternative strategies to cope better with economic down turns fall outside the scope of this article. 
Table 4: Significant correlation between long material lead times and other supply chain problems

\begin{tabular}{|l|c|c|c|c|}
\hline Problem & $\begin{array}{c}\text { Spearman's } \\
\text { rank-order } \\
\text { correlation }\end{array}$ & $\begin{array}{c}\text { Sig } \\
\text { (2-tailed) }\end{array}$ & Mean & $\mathbf{N}$ \\
\hline Internal supply chain problems & & & & \\
\hline Output based on rigid marketing forecasting & $.367^{\star}$ & .022 & 3.39 & 39 \\
\hline Shortage of a key material & $.358^{\star}$ & .032 & 3.03 & 36 \\
\hline Capacity limitations due to customer order fluctuations & $.436^{\star *}$ & .006 & 4.05 & 39 \\
\hline Customer-side problems & & & & \\
\hline Cancellation of orders (after the recent economic crisis) & $.323^{\star}$ & .033 & 5.02 & 44 \\
\hline Rapid changes in demand (in terms of quantity) patterns & $.546^{\star *}$ & .000 & 4.18 & 40 \\
\hline
\end{tabular}

* Correlation is significant at the 0.05 level (2-tailed).

** Correlation is significant at the 0.01 level (2-tailed).

Table 4 indicates a statistically significant correlation between the problem of long material lead times from supplier and a 'shortage of key materials' and 'changes in demand' is explainable. Due to long lead times the supply chain may not be able to be responsive to changes in the market demand, whether it is an increase or decrease in demand. In the case of an increase in demand long lead times can lead to a shortage of key materials.

Table 5: Significant correlation between delivery of right quality and other supply chain problems

\begin{tabular}{|l|c|c|c|}
\hline Problem & $\begin{array}{c}\text { Spearman's } \\
\text { rank-order } \\
\text { correlation }\end{array}$ & $\begin{array}{c}\text { Sig } \\
\text { (2-tailed) }\end{array}$ & N \\
\hline Internal supply chain problems & & & \\
\hline Output based on rigid marketing forecasting & $.386^{\star}$ & .038 & 29 \\
\hline Balancing inventory levels & $.361^{\star}$ & .046 & 31 \\
\hline Customer-side problems & & & \\
\hline Advance communication about market demand & $.449^{\star}$ & .006 & 36 \\
\hline Order fluctuations (prior to the recent economic crisis) & $.375^{\star}$ & .027 & 35 \\
\hline
\end{tabular}

* Correlation is significant at the 0.05 level (2-tailed).

Table 5 indicates a statistically significant correlation between the problem of delivery of the right quality from the ACM's suppliers, and 'balancing inventory' can be explained as follows: If poor quality materials or components are received from the supplier, they cannot be taken into the inventory despite the fact that it had been planned as such. The correlation 
with 'advance communication about market demand' and 'order fluctuation prior to the economic crisis' can be explained as follows: During economic growth times when market demand increases, if suppliers are not regularly updated on the market demand they could experience capacity problems which can put pressure on the production process which can result in lower quality products. Suppliers could decide to buy the additional materials or components they cannot produce themselves from other suppliers who might not be quality conscious, to deliver the full order.

Table 6: Significant correlation between on-time delivery and other supply chain problems

\begin{tabular}{|c|c|c|c|}
\hline Problem & $\begin{array}{l}\text { Spearman's } \\
\text { rank-order } \\
\text { correlation }\end{array}$ & $\begin{array}{l}\text { Sig } \\
\text { (2-tailed) }\end{array}$ & $\mathbf{N}$ \\
\hline \multicolumn{4}{|l|}{ Internal supply chain problems } \\
\hline Output based on customer (OEMs') forecasts to plan & $.386^{\star}$ & .024 & 34 \\
\hline $\begin{array}{l}\text { Design of materials flow system (based on international } \\
\text { best practice) }\end{array}$ & $.407^{\star}$ & .031 & 28 \\
\hline \multicolumn{4}{|l|}{ Customer-side problems } \\
\hline Trust between you and your 'best' customers & $.484^{\star}$ & .023 & 22 \\
\hline $\begin{array}{l}\text { Little/no assistance from customers to comply with their } \\
\text { requirements }\end{array}$ & $.387^{\star}$ & .020 & 36 \\
\hline Cancellation of orders (after the recent economic crisis) & $.476^{\star \star}$ & .003 & 36 \\
\hline $\begin{array}{l}\text { Excessive slow-moving inventory due to cancellation } \\
\text { of orders }\end{array}$ & $.379 *$ & .016 & 40 \\
\hline
\end{tabular}

* Correlation is significant at the 0.05 level (2-tailed).

** Correlation is significant at the 0.01 level (2-tailed).

Table 6 indicates a statistically significant correlation between the problem of on-time delivery and other important problems on both the internal supply chain and distribution sides of the supply chain. This can only be explained meaningfully from the customer side. The supply chain partners need to plan according to 'OEMs' forecasting'. If the demand forecasting is not accurate and the information is not accurately and efficiently communicated in good time to the rest of the supply chain, on-time delivery will be a problem. The problem with on-time delivery can cause a ripple effect through the supply chain and strain the relationship and 'trust between ACMs and OEMs'. 
Table 7: Significant correlation between supplier capacity limitations and other supply chain problems

\begin{tabular}{|l|c|c|c|}
\hline Problem & $\begin{array}{c}\text { Spearman's } \\
\text { rank-order } \\
\text { correlation }\end{array}$ & $\begin{array}{c}\text { Sig } \\
\text { (2-tailed) }\end{array}$ & N \\
\hline Internal supply chain problems & & & \\
\hline Output based on rigid marketing forecasts & $.473^{\star}$ & .006 & 32 \\
\hline Continuous improvement & $.596^{\star *}$ & .001 & 27 \\
\hline Customer-side problems & & & \\
\hline Trust between you and your 'best' customers & $.514^{\star}$ & .012 & 23 \\
\hline $\begin{array}{l}\text { Little/no assistance from customers to comply with their } \\
\text { requirements }\end{array}$ & $.391^{\star}$ & .020 & 35 \\
\hline
\end{tabular}

* Correlation is significant at the 0.05 level (2-tailed).

** Correlation is significant at the 0.01 level (2-tailed).

Table 7 indicates a statistically significant correlation between the problem of supplier capacity limitations and 'output based on rigid marketing forecasting' and 'trust between ACMs and OEMs'. This can be explained in the same way as in 'on-time delivery'. In stable economic conditions OEMs' optimistic forecasts can put strain on the capacity of the whole supply chain. Capacity limitations at a supplier can cause a ripple effect through the supply chain in the sense that the materials that are needed and expected are not delivered and 'trust' and 'relationships' are strained in the whole supply chain.

A summary of the significant correlations throughout the supply chain is presented in Figure 2 (compiled from Tables 2 to 7 ). Only those problems where there is a statistically significant correlation between all three sides of the supply chain are included in Figure 2 and will be discussed further below. 

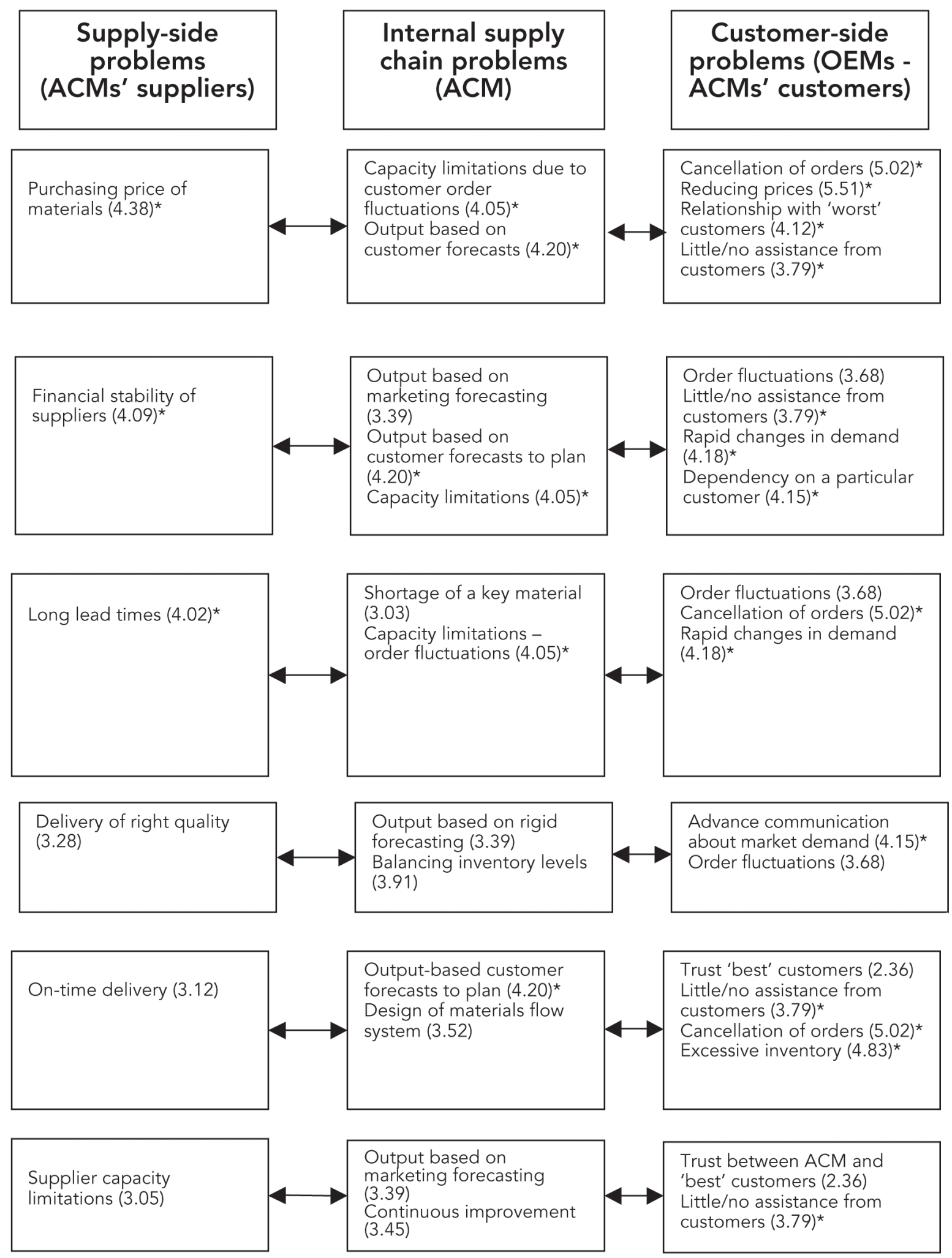

Figure 2: Correlations between supply-side and internal supply chain and customer-side problems ${ }^{2}$ (including (mean); * =significant)

2 Figure 2 indicates that items on the supply side (ACMs' suppliers) correlate with problems in internal process and customer-side problems. 
The findings in Tables 2 to 7 were discussed mainly from the supply side. Because SCM has a customer needs and satisfaction focus and supply chains are customer-demand driven, the findings in Figure 2 will be briefly discussed from the customer side.

The cancellation of orders from the OEMs creates problems throughout the supply chain. The planning of all the other parties in the supply chain is based on the OEMs' forecasts. The other parties have already committed themselves to the particular output. When OEMs cancel orders it causes financial losses for all the parties due to the long lead times and materials and components already in the chain.

OEMs put pressure on ACMs to reduce prices. ACMs do not operate efficiently due to capacity limitations, a problematic materials flow system and high purchasing prices of input materials. This puts strain on the relationship between the OEMs and ACMs, and the perception of little or no assistance from OEMs. Demand forecasting and the inefficient communication of demand forecasting information may also strain the relationships and create the perception of little or no assistance from OEMs.

The problems of order fluctuations and rapid changes in demand are closely related. Fluctuating orders and rapid changes in demand cause uncertainty in the supply chain, capacity limitations, a shortage of key materials and balancing inventory levels at ACMs, and delivery of the right quality by suppliers (as previously explained in Table 5).

The problem of dependency on particular customers makes the ACMs vulnerable to the OEMs' demand forecasting accuracy. The financial stability of ACMs and those of their supplier depends on the particular OEM.

Advance communication about market demand from OEMs is a significant problem and this can lead to ACMs struggling to balance inventory levels and to plan their production output. This can cause a ripple effect on the suppliers who might not be able to deliver the correct materials or components to the supply chain.

Trust between ACMs and some OEMs is a problem. This lack of trust can be caused by uncertainty about marketing forecasting which can further lead to suppliers not being able to deliver what is needed and when it is needed.

\section{SUMMARY}

OEMs are the dominant parties in automotive supply chains and balance their production loading in advance. Based on this production loading, OEMs prepare a production schedule which is communicated to their suppliers (ACMs). ACMs, in turn, base their forecasting on 
this schedule and provide their supplier with their forecasting. Rapid changes in demand and cancellation of orders by OEMs should be communicated in good time to the ACMs (advance communication about market demand) who in turn should communicate them in good time to their suppliers. The communication of real-time data and expected changes is vital, particularly when lead times in the supply chain are lengthy. When demand increases, long lead times may lead to poor responsiveness of the supply chain; if demand decreases, the ACM could face the risk of obsolescence and difficulty in balancing inventory levels should changes in demand not be communicated in time. The business risk increases when ACMs are dependent on mostly one customer's business.

Failure to achieve on-time delivery by the ACM's supplier could impact negatively on the trust between the ACM and its customer. One could argue that an ACM's supplier's failure in meeting delivery deadlines could result in the ACM experiencing a shortage of a key material. This, in turn, could impact on the ACM meeting its customer's delivery lead times, which would negatively influence the trust between the parties. This failure could impact negatively on the ACM's production and delivery deadlines, and the ACM would receive little or no assistance from its customers to comply with their (the customer's) requirements.

\section{CONCLUSION}

The conclusion can be reached that decisions made and/or problems experienced in one part of the supply chain affect other parts or levels of the supply chain. In particular, the dependence of the efficiency of the whole supply chain on demand forecasting and the communication of this information to the whole supply chain became clear. There are also correlations that show a strained relationship between ACMs and their customers (OEMs), and the effect of this on other levels in the supply chain.

If the problems identified in this study are compared to the critical success factors for SCM in the automotive industry identified earlier in the literature study, it becomes clear that the automotive supply chains experience shortcomings with regard to:

- integrated organisational structures that enable the supply chain to operate as a single synchronised entity

- an environment for excellent processes for implementing the strategy, which embraces all plan-source-make-deliver operations

- reliable information using integrated technology to support effective supply chain planning, execution and decision making. 


\section{RECOMMENDATIONS}

It is recommended that ACMs seek assistance from and develop closer working relationships with OEMs. The creation of the closer working relationship between the parties would enable them to work together on the reduction of waste, share information, and co-operate with continuous improvement, in designing an efficient materials system. A better relationship between the parties could also motivate OEMs to be more careful in making and implementing decisions that impact on the supply side of the supply chain, such as forecasting, planning and cancelling orders.

A significant problem from the perspective of balancing supply and demand is the issue of output based on customer forecasts. It is recommended that communications be improved between ACMs and OEMs and that OEMs review and alter their forecasts on a shorter interval basis in line with fluctuating sales demand. This would help ACMs to adjust the inflow of materials and components, and ultimately prevent an accumulation of inventories of raw materials and finished goods. It is also suggested that OEMs, ACMs and second-and third-tier suppliers work closer together to reduce inventories throughout the supply chain. This could be achieved by a real-time information system between ACMs, their customers (OEMs) and their suppliers. This would alleviate both lead time and inventory problems. In addition continuous replenishment programmes and collaborative planning, forecasting and replenishment and complete visibility of inventory through the supply chain could be implemented.

In the context of dependency on a particular customer, it is recommended that ACMs expand their customer base away from dependency on the OEMs, into the direct part sales market and the export market. However, in order to be able to export, ACMs need to become more competitive, and all the other problems and inefficiencies need to be resolved.

\section{Limitations and further research}

Little literature exists on the effect of problems or inefficiencies in one part of the supply chain affecting the supply chain efficiency as a whole. As such the article is based on general principles of the supply chain concept, which the researchers believe is not implemented to its fullest extent in automotive supply chains in South Africa. In this limitation perhaps lies the contribution of this article. This article made an effort to show the effect of a particular problem or inefficiency (for example a lack of demand information sharing) on other parts of the supply chain.

Further research opportunities lie in the actual measurement of the effect of inefficiencies at one place of the supply chain on the supply chain efficiency as a whole. 
A further limitation of the study is that it represents supply chain problems as perceived by ACMs. In addition, the qualitative part of the questionnaire did not yield rich enough information as had been hoped for, which could have led to more in-depth insight into the problems. This study should therefore be followed up with a qualitative study of various parties or stages of the supply chain to really pinpoint the origin, causes and implications of these problems.

Only component manufacturers who were members of NAACAM were included in the study. Therefore, the findings cannot be generalised to all ACMs in South Africa. 


\section{REFERENCES}

Bennett, D. \& O'Kane, J. 2006. Achieving business excellence through synchronous supply in the automotive sector. Benchmarking: An International Journal. 13(1/2):12 -22

Burt, D.N., Petcavage, S. \& Pinkerton, R. 2010. Supply management. 8th edition. Boston: Irwin McGraw-Hill.

Cagliano, R., Caniato, F. \& Spina, G. 2006. The linkage between supply chain integration and manufacturing improvement programmes. International Journal of Operations and Production Management. 26(3):282-99.

Candler, R. 1998. The influence of eastern and western business cultures in the automotive industry. University of Bristol. http://www.dig.bris.ac.uk/teaching/o_a_hf/rcand/rcand.htm. [Accessed 21 April 2006].

Fawcett, S.E., Ellram, L.M. \& Ogden, J. 2007. Supply chain management: from vision to implementation. Upper Saddle River, NJ: Pearson Prentice-Hall.

Gabru, F. 2008. Audit tool identifies supply chain gaps and improvement strategies. Engineering News. 25 July. http://www.aids.co.za/index [Accessed 19 January 2010].

Handfield, R.B., Monczka, R.M., Giunipero, L.C. \& Patterson, J.L. 2009. Sourcing and supply chain management. 4th edition. Mason, $\mathrm{OH}$ : South-Western, Cengage Learning.

Heizer, J. \& Render, B. 2008. Principles of operations management. 7th edition. Upper Saddle River, NJ: Prentice Hall.

Humphrey, J. \& Memedovic, O. 2003. The global automotive industry value chain: what prospects for upgrading by developing countries. Vienna: United Nations Industrial Development Organisation (UNIDO).

Humphreys, P.K., Huang, G., Cadden, T., \& Mclvor, R. 2007. Integrating design metrics within the early supplier selection process. Journal of Purchasing \& Supply Management. 13:42-52.

Lockström, M., Schadel, J., Harrison, N. \& Moser, R. 2009. Status quo of supplier integration in the Chinese automotive industry: a descriptive analysis. Proceedings of 18th IPSERA Conference, 5-8 April, Wiesbaden, Germany, pp.1315-27. 
Morris, D., Donnelly, T. \& Donnelly, T. 2004. Supplier parks in the automotive industry. Supply Chain Management: An International Journal. 9(2):129-33.

NAACAM. 2009. NAACAM BBEEE Bulletin, 9 March. www.naacam.co.za [Accessed 8 August 2009].

Power, D. 2005. Supply chain management integration and implementation: a literature review. Supply Chain Management: An International Journal. 10(4):252-63.

Simchi-Levi, D., Kaminsky, P. \& Simchi-Levi, E. 2009. Designing and managing the supply chain: concepts, strategies and case studies. 3rd edition. New York: McGraw-Hill.

Stevenson, W.J. 2005. Operations management. 8th edition. International edition. Boston: McGraw-Hill.

- 2009. Operations management. 10th edition. International edition. Boston: McGraw-Hill.

Sundaram, R.M. \& Metha, S.G. 2002. A comparative study of three different SCM approaches. International Journal of Physical Distribution and Logistics. 32(7):532-55.

Van Donk, D.P., Akkerman, R. \& Van der Vaart, T. 2008. Opportunities and realities of supply chain integration: the case of food manufacturers. British Food Journal. 110(2):218-35.

Van Weele, A.J. 2010. Purchasing \& supply chain management. 5th edition. Hampshire, UK: Cengage Learning.

Venter, I. 2009. Auto bosses wring their hands over SA's declining competitiveness. Can the situation be salvaged? Engineering News. 30 October. http://www.engineeringnews.co.za/ article/auto-bosses-wring-their-hands [Accessed 20 July 2010].

Wisner, J.D., Tan, K. \& Leong, G.R. 2009. Principles of supply chain management: a balanced approach. 2nd edition. Mason, $\mathrm{OH}$ : South-Western Cengage Learning. 